\title{
nature
}

\section{The wages of spin}

Steps to increase the transparency of the procedures used to judge the safety of genetically modified foods are to be welcomed. The scientific advice on which such judgements are made must reflect the same openness.

$\mathrm{T}$ he British government found itself treading on thin ice last week. In a bid to reduce public distrust of genetically modified (GM) food, it announced that consumer and ethics representatives will be appointed to two new "over-arching" bodies responsible for monitoring developments in human genetics and the agricultural use of biotechnology, respectively (see page 287). At the same time, it has resisted demands for broadening the membership of technical advisory committees to include non-scientist members.

The day before the new arrangements were announced, however, a letter was leaked to the media indicating the existence within the Cabinet Office of a 'Biotechnology Presentation Group' keen — among other things - to see editorial changes to the scientific report on which the government based its statement that there is "no evidence" that GM food is harmful, and to 'clear' its final draft. There is no evidence that the report was, in fact, modified at the group's request. But the suspicion understandably remains that it might have been, particularly in the light of the presentation group's stated desire to see prominence given elsewhere to the benefits of the technology.

Of course, the environmentalist groups who leaked the letter have little to complain about when it comes to 'spinning' news headlines. Much newspaper space, for example, was also devoted last week to attempting - on the basis of a letter to one such group - to portray Sir Robert May, the chief scientific adviser, as being at odds with the government on whether a moratorium should be placed on the commercial planting of GM crops. The government, although rejecting such demands, has refused to give the green light to such planting before the results of field trials have shown them to be safe; May merely said that he felt this would probably take several years to achieve.

Yet this does little to justify the government responding in kind, particularly at a time when public trust in official spokesmen is already low. Memories remain fresh of cabinet ministers issuing assurances that there was "no evidence" of a link between BSE and Creutzfeldt-Jakob disease. The refrain heard last week from supermarkets and their customers in response to similar statements about GM crops - "why should we believe them now?" — indicates the size of the credibility gap that remains to be bridged.

It is both easy and tempting to make the press the scapegoat for this state of affairs. Few would deny that some recent headlines, largely fuelled by circulation wars among middle-market newspapers, have blatantly distorted the interpretation of scientific evidence about the potential hazards of GM crops. Indeed, the recent behaviour of such newspapers has prompted the House of Commons Select Committee on Science and Technology to propose that cases of scientific inaccuracy should be reported to the Press Complaints Commission.

This strategy might be appropriate if questions concerning the safety of GM crops could be reduced to straightforward scientific 'truths'. But they seldom are. A more robust route would be to accept that the confusion between fact and interpretation is inevitable in a field as controversial as this, and to concentrate on providing people with the means to distinguish between the two.

One essential is to preserve the integrity of the peer-review process; papers that have been endorsed in this way — such as that published last week on the potential threats to the monarch butterfly from genetically engineered corn (see Nature 399, 214; 1999) — carry far greater legitimacy than those whose conclusions have not been carefully checked by scientific peers. A second is to ensure that the uncertainties in the scientific evidence, particularly in outlining potential longterm side effects, are given their proper weight when the scientific advice offered to ministers is turned into political practice.

From this point of view, the greater transparency promised by the government through the creation of its two broad monitoring bodies is to be welcomed. There remains a danger, however, that unless these are seen to be truly independent, not only of government (and industry) priorities, but also of a 'scientistic' mindset that limits the reflections of scientists and technical committees to that which is known, rather than that which can be envisaged, the process will remain within a straitjacket. After BSE, the consumer is no longer reassured by the statement, "there is no evidence that ..." The most appropriate forms of both government reassurance and scientific advice are now ones that take this fact and its implications actively into account.

\section{A sorry affair}

\section{A patent dispute involving allegations of scientific misconduct mars the image of the biotechnology industry.}

Aature insists on the retraction of papers it has published that

$N$ are subsequently shown to be false. But sometimes that is easier said than done, especially when co-authors of the original papers disagree over whether there is any fault at all.

Such occasions are, thankfully, rare. This issue contains an example that is even more unusual. At the heart of a billion-dollar lawsuit that has just entered the phase of jury deliberation (see page 289) are the contradictory statements of scientists as to whether a plasmid discovered at and patented by the University of California at San Francisco formed the crucial basis of a critical experiment in the early commercial success of the company Genentech, Inc.

The conflict can be seen starkly in separate letters addressed to this journal (see pages 297-298). Dennis Henner and current and former colleagues from Genentech deny misrepresentation in a subsequent Nature paper describing these experiments, and using stolen materials. In sharp contrast, their co-researcher Peter Seeburg confesses to what he describes as "a technical inaccuracy".

Nature is in no position to arbitrate. It is now up to a San Francisco jury to decide who has made the most convincing case, and even that judgement is unlikely to be final. It is some consolation that neither the paper itself - nor the value of the human growth hormone to which it has led - are in dispute. But the picture of commercial pressures lurking in the background does little credit to the public reputation of the biotechnology industry - and makes the adoption of guidelines for sharing research tools between federally sponsored researchers and industry (see page 291) even more urgent. 